SANTANA NETO, Hamilton Gomes de. Ética como valor normativo na conduta do advogado: responsabilidade democrática no acesso à justiça. Revista Eletrônica Direito e Política, Programa de Pós-Graduação Stricto Sensu em Ciência Jurídica da UNIVALI, Itajaí, v.16, n.3, 30 quadrimestre de 2021. Disponível em: www.univali.br/direitoepolitica - ISSN 1980-7791.

\title{
ÉTICA COMO VALOR NORMATIVO NA CONDUTA DO ADVOGADO: RESPONSABILIDADE DEMOCRÁTICA NO ACESSO À JUSTIÇA
}

\author{
ETHICS AS A NORMATIVE VALUE IN THE CONDUCT OF LAWYERS: DEMOCRATIC \\ RESPONSABILITY IN JUSTICE ACCESS
}

Hamilton Gomes de Santana Neto ${ }^{1}$

\section{RESUMO}

O estudo da ética engloba inúmeras concepções filosóficas do pensamento humano; afinal, aquela está no homem, não nas coisas. No entanto, este artigo tem como foco discorrer sobre a ética na seara profissional do advogado, destacando o viés teórico e sua importância na construção de condutas morais, normativas, ao agente da advocacia. Assim, a análise da ética profissional na advocacia revela-se importante para debater, na prática, a influência e responsabilidade do advogado na construção do corpo social através de sua essencialidade ao acesso à Justiça, destacando seu papel como ator na construção da democracia.

PALAVRAS-CHAVE: Ética; Advogado; Condutas morais; Normatividade; Acesso à Justiça.

\begin{abstract}
The study of ethics encompasses numerous philosophical conceptions of human thought; after all, that one is in man, not in things. However, this article is focused on discussing ethics in the professional field of lawyers, highlighting the theoretical gore and its importance in the construction of moral, normative behaviors for the lawyer. Thus, the study of professional ethics in law is important to debate, under a practical perspective, the lawyer's influence and responsibility in the construction of the social body through its essential access to justice, highlighting its role as an actor in the construction of democracy.
\end{abstract}

\footnotetext{
${ }^{1}$ Mestrando em Direito pela Universidade Federal do Amazonas. - UFAM. Especialista em Direito Processual pela Escola Superior da Magistratura do Amazonas - ESMAM. Especialista em Direitos Humanos pela Escola Superior de Advocacia do Amazonas - ESA-OAB/AM. Graduado pela Faculdade de Direito da UFAM. Professor Voluntário de Direito Processual Civil na Faculdade de Direito da UFAM. Técnico Judiciário em Assessoria de Desembargador do TJ/AM. hgsneto1994@gmail.com.
} 
SANTANA NETO, Hamilton Gomes de. Ética como valor normativo na conduta do advogado: responsabilidade democrática no acesso à justiça. Revista Eletrônica Direito e Política, Programa de Pós-Graduação Stricto Sensu em Ciência Jurídica da UNIVALI, Itajaí, v.16, n.3, 30 quadrimestre de 2021. Disponível em: www.univali.br/direitoepolitica - ISSN 1980-7791.

KEYWORDS: Ethic; Attorney; Moral conduct; Normativity; Access to Justice.

\section{INTRODUÇÃO}

O exercício da advocacia não é uma prática recente, havendo manifestação de seus traços nas mais antigas escrituras da humanidade.

A título de exemplo, na Bíblia, a figura do advogado, ou ao menos o seu mister, já se mostrava aparente, apesar da incipiência. Basta-se notar a conhecida história de Moisés, em Êxodo, no famoso episódio de apedrejamento de Maria Madalena, dentre outras passagens em que figuras Bíblicas já abordavam a defesa da pessoa num anseio pelo ideal de Justiça².

Há quem diga que os primeiros traços da profissão teriam nascidos há, pelo menos, três milênios antes de Cristo, na região da Suméria, significando, numa visão elementar, a atividade para defesa de pessoas, direitos, bens e interesses ${ }^{3}$.

A par da discussão acerca da origem e do momento de sua aparição, tal prática ganhou notório destaque na Grécia antiga, através das clássicas histórias dos oradores, como Desmóstenes, que, defendendo os interesses das pessoas locais de Atenas, conquistou influência política à época ${ }^{4}$.

De se notar, portanto, que o exercício dos atributos da advocacia, para além da defesa de interesses individuais, carrega consigo nítida capacidade de empoderamento do discurso para afetar toda uma coletividade.

Não à toa, para Jürgen Habermas, o agir comunicativo fundamenta-se na força sem violência do discurso argumentativo ${ }^{5}$.

\footnotetext{
2BARBOSA, Júlio César Tadeu. O que é Justiça. São Paulo. Editora Brasiliense, $4^{a}$ edição, 1984.

3 LÔBO, PAULO LUIZ NETTO. Comentários ao Estatuto da Advocacia e da OAB. São Paulo: Saraiva, 10a ed., 2017, p. 19.

${ }^{4}$ ROSSI, João Baptista Prado. Reflexões sobre a advocacia e a magistratura. São Paulo: OABSP, 1990, p.15.

${ }^{5}$ HABERMAS, Jürgen. A ética da discussão e a questão da verdade. Tradução Marcelo Brandão Cipolla. $2^{a}$ ed. São Paulo: Martins Fontes, 2007, p.24.
} 
SANTANA NETO, Hamilton Gomes de. Ética como valor normativo na conduta do advogado: responsabilidade democrática no acesso à justiça. Revista Eletrônica Direito e Política, Programa de Pós-Graduação Stricto Sensu em Ciência Jurídica da UNIVALI, Itajaí, v.16, n.3, 30 quadrimestre de 2021. Disponível em: www.univali.br/direitoepolitica - ISSN 1980-7791.

O labor do advogado, pelo discurso argumentativo, é, pois, sua grande ferramenta e, se mal versada, pode causar danos consideráveis na medida em que lida com interesses humanos ${ }^{6}$.

Logo, a responsabilidade para com seu mister é de grande valia não só ao advogado, mas às partes que Ihe confiam sua representação, surgindo, aqui, a questão acerca da ética e a importância desta como diretriz normativa a ser seguida pelos profissionais da advocacia através de condutas morais e responsáveis para com seu papel constitucional de função essencial à Justiça.

\section{1. ÉTICA COMO NORMA/VALOR À ADVOCACIA}

Tratar de ética é missão que não esgota em si, pois adentra no campo das inúmeras concepções filosóficas do pensamento humano, fazendo surgir a famosa e subjetiva pergunta: o que é ética? $\mathrm{E}$, para o presente estudo, a pergunta que interessa é: o que tal instituto teria a ver com a profissão de advogado?

Longe de traçar o que seja, em conceito hermético, o estudo da ética deve se preocupar em transmitir os pensamentos teóricos acerca das "melhores" condutas 7 para o plano pragmático, ou seja, o mundo dos fatos, norteado e construído por atos que, no caso do profissional da advocacia, devem ser morais e tomadas com responsabilidade social.

No estudo em apreço, o foco é analisar a importância de tal profissional do direito e os impactos de sua atuação na sociedade, destacando as condutas morais

\footnotetext{
6 Desprezar os outros, ou seja, negar-lhes o respeito devido aos seres humanos em geral, é em todas as situações contrário ao dever, uma vez que se tratam de seres humanos [...] (KANT, Immanuel. Fundamentação da metafísica dos costumes. Trad. de Guido Antônio de Almeida. São Paulo: Discurso Editorial: Barcarolla, 2009, p. 306).

7 "O termo ethos, ao lado de pathos e logos, designa, na Grécia clássica, uma das dimensões ontológicas fundamentais da vida humana. Ética constitui, além da doutrina do bom e do correto, da "melhor" conduta, a teoria do conhecimento e realização desse desiderato. (...)" (ADEODATO, João Maurício. Ética e retórica: para uma teoria da dogmática jurídica. Saraiva: 2002, pp. 185-186).
} 
SANTANA NETO, Hamilton Gomes de. Ética como valor normativo na conduta do advogado: responsabilidade democrática no acesso à justiça. Revista Eletrônica Direito e Política, Programa de Pós-Graduação Stricto Sensu em Ciência Jurídica da UNIVALI, Itajaí, v.16, n.3, 30 quadrimestre de 2021. Disponível em: www.univali.br/direitoepolitica - ISSN 1980-7791.

esperadas de tal categoria e ressaltando, ainda, o valor normativo de tais diretrizes.

Afinal, no mundo moderno, os "operadores do direito" devem ser vistos não mais como meros aplicadores de regras frias, mas como partes de um conjunto maior, onde as normas jurídicas se preocupam com o cenário fático (efetividade social) e buscam aspecto axiológico, valorativo (o bem comum, o ideal de Justiça).

$\mathrm{Na}$ visão de Max Scheler, toda e qualquer atividade humana, enquanto intencionalmente dirigida à realização de um valor, deve ser considerada conduta ética ${ }^{8}$.

Tal raciocínio serviu de base à obra de Miguel Reale, que há muito tempo já trazia a estrutura tridimensional do direito, na sua célebre concepção de que este é fato, norma e valor.

Para o professor, fatos, valores e normas se implicam e se exigem reciprocamente, o que se reflete também no momento em que o jurisperito (advogado, juiz ou administrador) interpreta uma norma ou regra de direito para dar-Ihe aplicação ${ }^{9}$.

As normas éticas não envolvem apenas um juízo de valor sobre os comportamentos humanos, mas culminam na escolha de uma diretriz considerada obrigatória numa coletividade, razão pela qual, para além de meros preceitos éticos, são, pois, normas e, portanto, devem ser respeitadas ${ }^{10}$.

Assim, a advocacia, como profissão, não deve destoar de tais juízos de valores, devendo seguir as diretrizes morais de determinado grupo como verdadeiras normas, ou seja, com viés de observância, de obrigatoriedade frente ao corpo social.

${ }^{8}$ SCHELER, Max. Esencia y formas de la simpatía. Buenos Aires: Editorial Losada, S.A., 2004, p. 127.

${ }^{9}$ REALE, Miguel. Lições preliminares de Direito. 27 ed. São Paulo: Saraiva, 2002, p. 66.

${ }^{10}$ REALE, Miguel. Lições preliminares de Direito. 27 ed. São Paulo: Saraiva, 2002, p.33. 
SANTANA NETO, Hamilton Gomes de. Ética como valor normativo na conduta do advogado: responsabilidade democrática no acesso à justiça. Revista Eletrônica Direito e Política, Programa de Pós-Graduação Stricto Sensu em Ciência Jurídica da UNIVALI, Itajaí, v.16, n.3, 30 quadrimestre de 2021. Disponível em: www.univali.br/direitoepolitica - ISSN 1980-7791.

Deve-se salientar que o campo da ética é deveras subjetivo, pois diz respeito ao sujeito humano. No entanto, tal característica não Ihe tira o caráter normativo, muito porque, mesmo os preceitos principiológicos devem ser considerados na formação da norma.

De se notar, à guisa do tema, que, na visão de Eros Grau, norma seria gênero do qual são espécies as regras e os princípios ${ }^{11}$, fator que corrobora, ainda mais, 0 enquadramento da ética como, ao menos, integrante de uma norma de conduta social.

Ao plano concreto, portanto, o viés ético impulsiona a conduta moral que, na sociedade brasileira hodierna, deve ter como escopo a tutela dos direitos fundamentais, sendo estes verdadeiros direitos humanos positivados na ordem jurídica ${ }^{12}$.

Repise-se, a postura moral, ou seja, de probidade para com o coletivo, enaltece a advocacia em seu mister, principalmente no mundo moderno onde confiança é um dos valores mais caros nas relações interpessoais ${ }^{13}$.

Tal fato, ainda, ganha amplitude ao tratarmos da figura do advogado, notadamente por ser este considerado uma das "funções essenciais à justiça", nos termos do art. 133 da Constituição Federal de $1988^{14}$.

\footnotetext{
${ }^{11} \mathrm{GRAU}$, Roberto Eros. O direito posto e o direito pressuposto. Malheiros Editores Ltda. São Paulo, 1996, p. 19.

${ }^{12}$ SARLET, Ingo Wolfgang. A eficácia dos Direitos Fundamentais. 10. ed. Porto Alegre: Livraria do Advogado, 2009.

${ }^{13}$ (...)A confiança está basicamente vinculada, não ao risco, mas à contingência. A confiança sempre leva à conotação de credibilidade em face de resultados contingentes, digam estes respeito a ações de indivíduos ou à operação de sistemas. No caso de confiança em agentes humanos, a suposição de credibilidade envolve a atribuição de "probidade" (honra) ou amor. É por isto que a confiança em pessoas é psicologicamente conseqüente para o indivíduo que confia: é dado um refém moral à fortuna. (GIDDENS, Anthony. As consequências da modernidade. Tradução de Raul Fiker. São Paulo: Editora UNESP, 1991, p. 35).

${ }^{14}$ Constituição Federal de 1988: Art. 133. O advogado é indispensável à administração da justiça, sendo inviolável por seus atos e manifestações no exercício da profissão, nos limites da lei.
} 
SANTANA NETO, Hamilton Gomes de. Ética como valor normativo na conduta do advogado: responsabilidade democrática no acesso à justiça. Revista Eletrônica Direito e Política, Programa de Pós-Graduação Stricto Sensu em Ciência Jurídica da UNIVALI, Itajaí, v.16, n.3, 30 quadrimestre de 2021. Disponível em: www.univali.br/direitoepolitica - ISSN 1980-7791.

Logo, o profissional da advocacia não se limita em sua pessoa, mas representa instrumento/função essencial ao ideal de justiça, razão pela qual seu protagonismo ganha impacto social relevante, sendo expressão, inclusive, da democracia local.

É que, como já ressaltado ao tratarmos dos oradores gregos, as atribuições dos patronos envolvem a defesa de interesses pessoais que, muitas das vezes, acabam por ganhar notório destaque com o discurso argumentativo que interessa, por óbvio, para além da relação jurídico-processual, refletindo, assim, na formação do regime democrático ${ }^{15}$.

Indo além da teoria, este raciocínio é corroborado diante do cenário fático de frenesi no número de demandas judiciais, confira-se o Relatório Justiça em Números mais atual, de 2020, do Conselho Nacional de Justiça:

\section{Figura 49: Casos pendentes, por ramo de justiça}

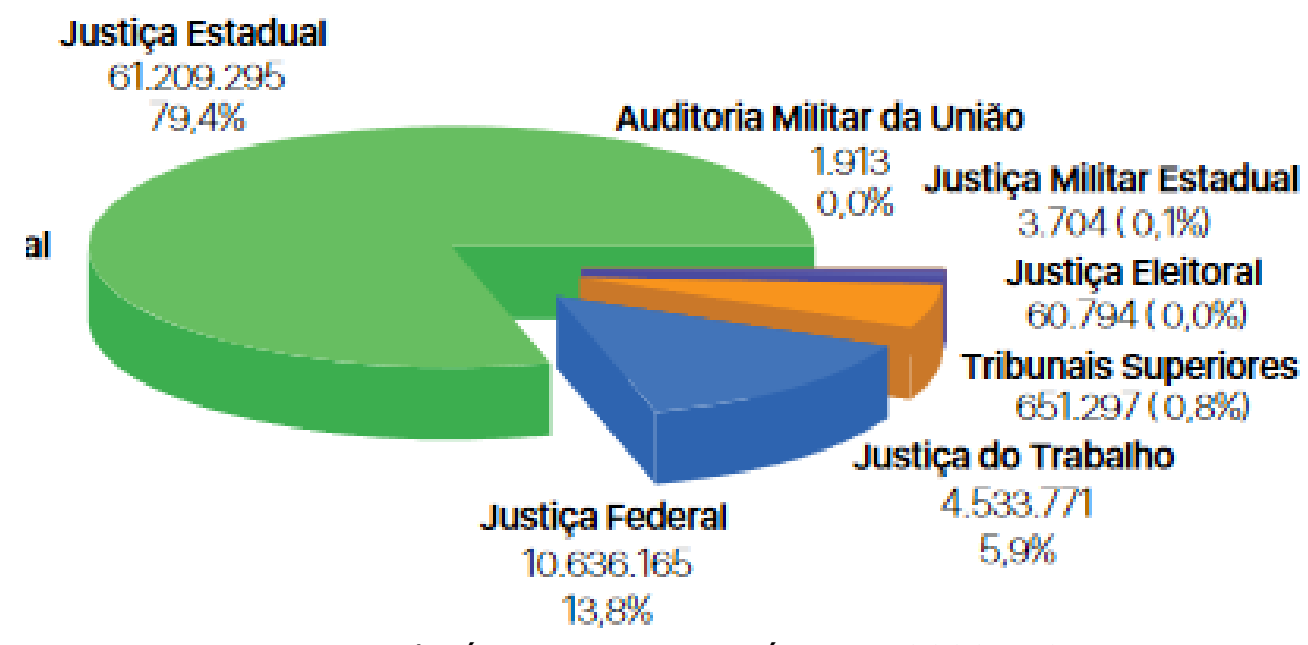

Fonte: Relatório Justiça em Números 2020 - CNJ

Ora, a expressiva quantidade de processos reflete, naturalmente, nas diversas searas sociais, razão pela qual as condutas coordenadas dos patronos podem, facilmente, influenciar práticas reiteradas de comportamentos.

\footnotetext{
${ }^{15}$ RAMOS FILHO, Carlos Alberto de Moraes; CASAS MAIA, Maurílio. A defensoria pública como expressão e instrumento do regime democrático. In. Democracia e constitucionalismo: riscos, pressões e resiliência. Org. Rafael da Silva Menezes. 1 ed. Manaus/AM: Green Tree Books Edições Jurídicas, 2021.
} 
SANTANA NETO, Hamilton Gomes de. Ética como valor normativo na conduta do advogado: responsabilidade democrática no acesso à justiça. Revista Eletrônica Direito e Política, Programa de Pós-Graduação Stricto Sensu em Ciência Jurídica da UNIVALI, Itajaí, v.16, n.3, 30 quadrimestre de 2021. Disponível em: www.univali.br/direitoepolitica - ISSN 1980-7791.

Assim, espera-se por condutas morais, e não imorais, na medida em que a classe profissional detém notória capacidade de expressão através de seu mister em juízo.

Não obstante, a responsabilidade do patrono vai além de sua causa, transcendendo para a formação de uma categoria forte e com voz para mudar a realidade coletiva.

Assim, as condutas imorais, ou seja, às margens dos patamares éticos, representam ameaça potencial à sociedade e à formação de seus pilares morais em busca da virtude na existência humana ${ }^{16}$, devendo o profissional ter consciência do impacto de sua atuação social e não se render apenas a interesses individuais ou que possam trazer prejuízos à estabilidade da comunidade.

\section{A ÉTICA COMO TEORIA: MORAL COMO PRÁTICA}

Ao falar de ética e condutas morais, distinções devem ser feitas para não se confundir os pensamentos.

No primeiro olhar, moral se relaciona com a regência das condutas e regras de determinada coletividade, ou seja, são normas não escritas que indicam o que a pessoa deve ou não fazer naquele grupo social.

Assim, a depender da sociedade e do fator tempo, a moral varia.

Demais disso, a concepção de moral tem relação com a noção do "bem". Tal pensamento teve como berço a Grécia antiga, entre os chamados estoicos e os epicuristas. Para aqueles, o "bem" consistiria na resignação, na virtude como única

${ }^{16}(. .)$.$A virtude, em Aristóteles, significa a ação. Significa uma prática, e não uma natureza. O homem$ virtuoso, portanto, é o homem ativo, que aprendeu pela prática.(...) (NALINI, José Renato. Ética geral e profissional. 7 ed. São Paulo: Editora Revista dos Tribunais, 2009, p. 59). 
SANTANA NETO, Hamilton Gomes de. Ética como valor normativo na conduta do advogado: responsabilidade democrática no acesso à justiça. Revista Eletrônica Direito e Política, Programa de Pós-Graduação Stricto Sensu em Ciência Jurídica da UNIVALI, Itajaí, v.16, n.3, 30 quadrimestre de 2021. Disponível em: www.univali.br/direitoepolitica - ISSN 1980-7791.

fonte da felicidade, ao passo que, para estes, a ideia do "bem" teria relação com o "prazer"17.

Longe de fechar o conceito, toma-se por base o conceito de "bem" como tudo aquilo que promove a pessoa de uma forma integral e integrada de modo que a moral favorece o direito positivo na medida em que Ihe empresta valores ${ }^{18}$.

Integral porque realiza a pessoa, e integrada porque condicionada aos interesses do próximo.

Logo, ao se estudar moralidade deve-se ter em mente um conjunto de valores que conduzem o comportamento, as decisões e as ações do ser humano em sociedade.

Ao revés, a ética é vista como universal, resultado do estudo de "diversas morais", possuindo caráter imutável de um grupo social para outro.

De se salientar, ainda, que, para os chamados utilitaristas, a ética visaria a "maior felicidade", não do próprio agente, mas ao maior número de pessoas envolvidas, sendo defendida a nobreza de caráter, avaliada e classificada de acordo com extensão de seus efeitos ao bem comum ${ }^{19}$.

Ao tratar da distinção entre ética e moral, Aristóteles ensina que ética só dependeria da vontade da pessoa e traça um paralelo com a concepção de virtude, sendo considerada um hábito que precisa ser cultivado, ou seja, exercido em sociedade ${ }^{20}$.

\footnotetext{
${ }^{17}$ NADER, Paulo. Introdução ao estudo do direito. $34^{a}$ ed. Rio de Janeiro:Forense, 2012, p.36. ${ }^{18}$ NADER, Paulo. Introdução ao estudo do direito. 34a ed. Rio de Janeiro:Forense, 2012, p.56. ${ }^{19}$ BENTHAM, Jeremy. Os pensadores. São Paulo: Abril Cultural, 1979, p. 65.

$20 "(. .$.$) Na concepção aristotélica, a ética só depende da vontade da pessoa. Para distinguir entre$ virtudes intelectuais e virtudes morais, Aristóteles exemplifica de maneira ainda hoje clara e apreensível: 'Não é, pois, por natureza, nem contrariando a natureza que as virtudes se geram em nós. Diga-se, antes, que somos adaptados por natureza a recebê-las e nos tornamos perfeitos pelo hábito'. (...)A virtude se obtém mediante o exercício: é um hábito. As aptidões, intelectuais ou físicas, são inatas. Para Aristóteles, a razão não basta. É preciso cultivar o hábito da virtude(...)"(NALINI, José Renato. Ética geral e profissional. 7 ed. São Paulo: Editora Revista dos Tribunais, 2009, p. 59).
} 
SANTANA NETO, Hamilton Gomes de. Ética como valor normativo na conduta do advogado: responsabilidade democrática no acesso à justiça. Revista Eletrônica Direito e Política, Programa de Pós-Graduação Stricto Sensu em Ciência Jurídica da UNIVALI, Itajaí, v.16, n.3, 30 quadrimestre de 2021. Disponível em: www.univali.br/direitoepolitica - ISSN 1980-7791.

Assim, num breve quadro resumo, para não se alongar a temática, tem-se o cenário da distinção entre ética e moral da seguinte forma elementar:

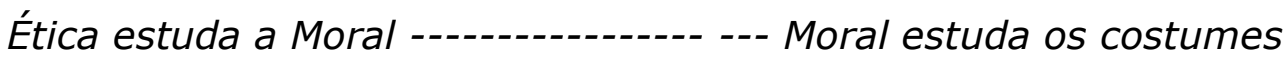

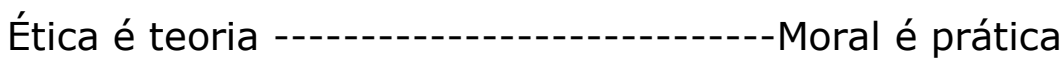

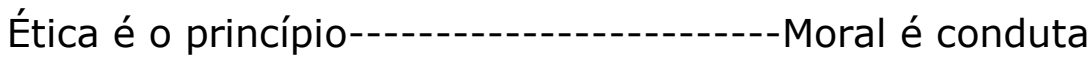

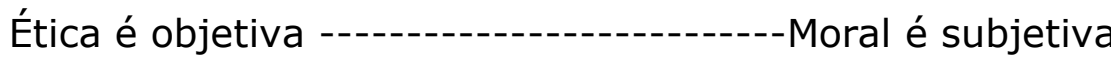

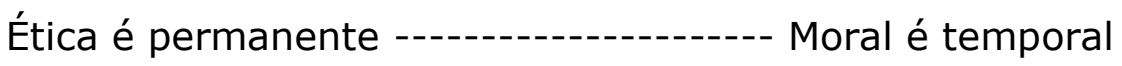

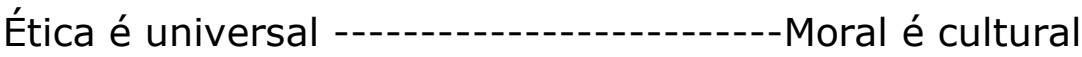

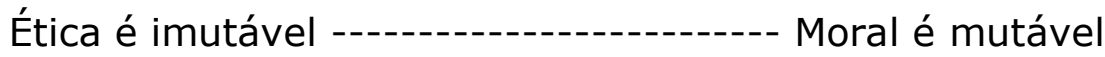

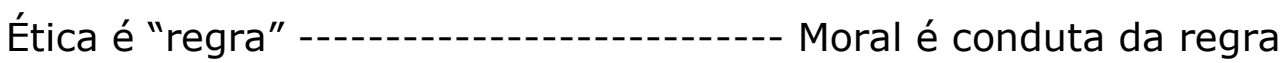

Fonte: elaborado pelo autor.

Conforme já salientado, o estudo de tais pensamentos remontam a concepções filosóficas infindáveis, não sendo o alvo deste estudo, mas meio para se chegar à análise central, qual seja: a normatividade de condutas morais ao profissional advogado.

Como exemplo de atitude moral esperada do profissional da advocacia, tem-se a prestação de contas para com seu cliente, conduta já prevista em regra positiva, mas decorrente, também, de preceito ético norteador de boas práticas do agente ${ }^{21}$.

21 (...)5. Nos termos do Código Civil e do Estatuto da Advocacia (Lei 8.906/94), a prestação de contas é obrigação inerente ao mandato judicial, cabendo ao advogado, mandatário, prestar contas pormenorizadas quando da conclusão dos serviços, sem prejuízo de outras prestações solicitadas pelo mandante a qualquer momento.(...)(REsp 1877742/DF, Rel. Ministra NANCY ANDRIGHI, TERCEIRA TURMA, julgado em 16/03/2021, DJe 25/03/2021). 
SANTANA NETO, Hamilton Gomes de. Ética como valor normativo na conduta do advogado: responsabilidade democrática no acesso à justiça. Revista Eletrônica Direito e Política, Programa de Pós-Graduação Stricto Sensu em Ciência Jurídica da UNIVALI, Itajaí, v.16, n.3, 30 quadrimestre de 2021. Disponível em: www.univali.br/direitoepolitica - ISSN 1980-7791.

Vale ressaltar que o Código de Ética da OAB não é tido como Lei Federal ${ }^{22}$, o que poderia ensejar dúvidas quanto à obrigatoriedade de tais condutas ao profissional da advocacia.

No entanto, como já ressaltado, as condutas morais, notadamente oriundas da teoria ética pela busca da virtude humana, detém, sim, sua força normativa e servem ao controle social.

\section{O PROFISSIONAL DA ADVOCACIA PARA ALÉM DO DIREITO}

Ao falar da advocacia, inevitavelmente, deve-se tratar acerca do campo de atuação profissional do advogado.

Muito se pensa sobre tal carreira como voltada exclusivamente ao campo do litígio judicial, notadamente com aplicação única, ou preponderantemente, do Direito.

Sucede que não é bem assim, ou, pelo menos, não deveria ser. Ora, o advogado é muito mais que mero profissional do Direito, é, pois, profissional social, atuando para além das regras positivadas ${ }^{23}$.

A atuação do advogado é próxima ao conflito social de modo que seu labor deve buscar uma pacificação da contenda e não incentivar o triste cenário de judicialização da vida ${ }^{24}$ com as demandas de massa ${ }^{25}$.

22 (...)6. Ressalta-se que as regras relativas ao Código de Ética e Disciplina da OAB são mencionadas para fins ilustrativos da limitação da liberdade contratual na fixação de honorários advocatícios, pois não se enquadram no conceito de lei federal (art.105, III, da CF).(REsp 1903416/RS, Rel. Ministro HERMAN BENJAMIN, SEGUNDA TURMA, julgado em 02/02/2021, DJe 13/04/2021).

${ }^{23}$ (...)Nesse cenário, a relevância da participação da advocacia é reconhecida não só por constituir função indispensável à administração da justiça, mas também por ser elemento essencial para dar concretude à garantia fundamental de acesso à justiça.(..) (REsp 1656322/SC, Rel. Ministro ROGERIO SCHIETTI CRUZ, TERCEIRA SEÇÃO, julgado em 23/10/2019, DJe 04/11/2019).

24 BARROSO, Luís Roberto. A Judicialização da Vida e o Papel do Supremo Tribunal Federal. Belo Horizonte: Forum, 2018, p. 64.

25 CAPPELLETTI, Mauro. Formações sociais e interesses coletivos diante da Justiça Civil. Revista de Processo. São Paulo. Ed. RT, ano 2, v. 5, p. 122-159, jan./mar. 1977. 
SANTANA NETO, Hamilton Gomes de. Ética como valor normativo na conduta do advogado: responsabilidade democrática no acesso à justiça. Revista Eletrônica Direito e Política, Programa de Pós-Graduação Stricto Sensu em Ciência Jurídica da UNIVALI, Itajaí, v.16, n.3, 30 quadrimestre de 2021. Disponível em: www.univali.br/direitoepolitica - ISSN 1980-7791.

Bem antes da concretização de tal fato social ${ }^{26}$ inquestionável, mecanismos de solução de conflitos já eram apresentados numa expressão do sistema multiportas ${ }^{27}$ de apaziguamento das lides.

Logo, a tendência da advocacia é, cada vez mais, abandonar tal cenário de disputas massificadas às portas do Judiciário e ganhar autonomia, independência para a solução dos conflitos sociais através de meios alternativos ${ }^{28}$.

E isso não é retrocesso, pelo contrário, a tutela dos direitos, em escala multitudinária, deve passar por uma reformulação, muito porque se vive, hoje, numa sociedade do frenesi consumerista.

Tal cenário contemporâneo traz consigo o surgimento dos conflitos de massa ${ }^{29}$, que, no Estado do Amazonas, por exemplo, já vem refletindo no número de ações judiciais, com a concentração das demandas no âmbito dos Juizados Especiais Cíveis.

Confira-se panorama mais recente de tal represamento através do gráfico demonstrativo do número de processos judiciais pendentes de análise e julgamento até o mês de maio de 2021, notadamente dos 10 juízos mais sobrecarregados.

\footnotetext{
${ }^{26}$ DURKHEIM, É. Da divisão do trabalho social. São Paulo: Martins Fontes, 1999.

27 SANDER, Frank E. A. The Multi-Door Courthouse: Settling Disputes in the Year 2000. Hein Online: 3 Barrister 18, 1976, p. 18.

28 SANDER, Frank E. A. Varieties of dispute processing. In: Levin, L. A.; Russel, W. R. (Edit.). The pound conference: perspectives on justice in the future. Saint Paul: West Publishing Co., 1979.

29 "(...)A sociedade moderna abre oportunidade a situações em que determinadas atividades podem trazer prejuízo aos interesses de grande número de pessoas, fazendo surgir problemas ignorados nas demandas individuais. O risco de tais lesões, que afetam simultaneamente inúmeros indivíduos ou categorias de pessoas, constitui fenômeno cada vez mais amplo e freqüente na sociedade contemporânea. Ora, se a sociedade atual é caracterizada por ser de produção e consumo de massa, é natural que passem a surgir conflitos de massa e que os processualistas estejam cada vez mais preocupados em configurar um adequado "processo civil coletivo" para tutelar os conflitos emergentes (...)" (MARINONI, Luiz Guilherme; ARENHART, Sérgio Cruz. Curso de direito processual civil: Procedimentos Especiais. 4. ed. São Paulo: Revista dos Tribunais, 2013, V. 5. p. 302).
} 
SANTANA NETO, Hamilton Gomes de. Ética como valor normativo na conduta do advogado: responsabilidade democrática no acesso à justiça. Revista Eletrônica Direito e Política, Programa de Pós-Graduação Stricto Sensu em Ciência Jurídica da UNIVALI, Itajaí, v.16, n.3, 30 quadrimestre de 2021. Disponível em: www.univali.br/direitoepolitica - ISSN 1980-7791.

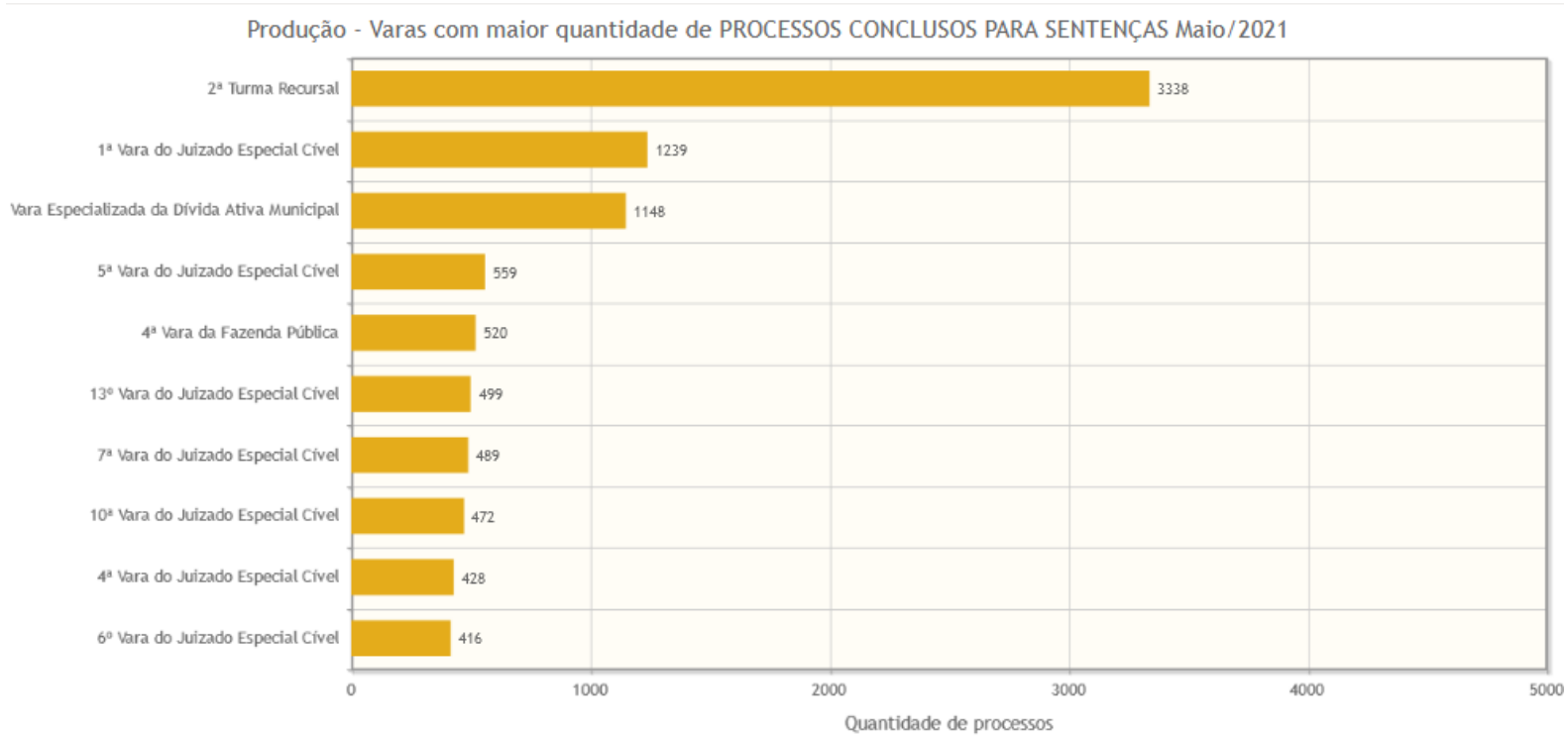

Fonte: Metas TJAM (http://metas.tjam.jus.br/index.xhtml)

De se notar, ainda, que as demandas em Juizados Especiais no Amazonas apontam para o fato social de judicialização da vida ${ }^{30}$, representando, no âmbito Amazônico, mais da metade do acerco processual:

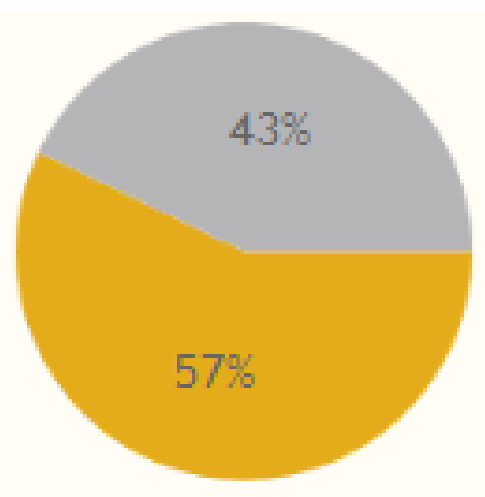

Influência das 10 varas com maior saldo

Influência das demais varas

Fonte: Metas TJAM (http://metas.tjam.jus.br/index.xhtml)

${ }^{30}$ BARROSO, Luís Roberto. A Judicialização da Vida e o Papel do Supremo Tribunal Federal. Belo Horizonte: Forum, 2018, p. 64. 
SANTANA NETO, Hamilton Gomes de. Ética como valor normativo na conduta do advogado: responsabilidade democrática no acesso à justiça. Revista Eletrônica Direito e Política, Programa de Pós-Graduação Stricto Sensu em Ciência Jurídica da UNIVALI, Itajaí, v.16, n.3, 30 quadrimestre de 2021. Disponível em: www.univali.br/direitoepolitica - ISSN 1980-7791.

Assim, a atuação do advogado no âmbito social é impactante, muito porque, para além dos números de ações processuais, tem-se por trás todo um reflexo na economia local, nas relações negociais, e, inclusive, na questão financeira do Estado. Explica-se.

Este emaranhado de ações acaba por influenciar não apenas nas prateleiras dos órgãos judicantes, mas na sociedade amazonense como um todo que, pelo represamento de demandas, tem seus direitos também represados.

Ora, o impacto financeiro dos processos reflete sobremaneira na arrecadação estatal, pois a capacidade econômica de pessoas físicas e jurídicas é gravemente afetada neste cenário de disputas desenfreadas.

Desta forma, a atividade financeira do Estado também é impactada e, por consequência, os direitos da população. Afinal, são necessários os recursos econômicos para perfectibilizar o bem comum ${ }^{31}$, finalidade do Estado, sendo esta um de seus elementos característicos ${ }^{32}$.

$\mathrm{Na}$ interpretação do Superior Tribunal de Justiça, a advocacia não é atividade mercantil e não vislumbra exclusivamente o lucro, devendo-se a relação entre advogado e cliente ser pautada no primado da confiança ${ }^{33}$.

Assim, como já salientado, apesar do Estatuto da Ordem dos Advogados do Brasil ter natureza jurídica de Lei Federal (n 8.906, de 04 de julho de1994), o Código de Ética e Disciplina não teve o mesmo tratamento ${ }^{34}$.

\footnotetext{
${ }^{31}$ RAMOS FILHO, Carlos Alberto de Moraes. Curso de direito financeiro. São Paulo. Saraiva, 2012, p.24-25.

32DALLARI, Dalmo de Abreu. Elementos de teoria geral do Estado. 31 ed. São Paulo: Saraiva, 2012 , p. 107.

33 "(...)6. Considerando que a advocacia não é atividade mercantil e não vislumbra exclusivamente o lucro, bem como que a relação entre advogado e cliente é pautada na confiança de cunho recíproco, não é razoável - caso ocorra a ruptura do negócio jurídico por meio renúncia ou revogação unilateral mandato - que as partes fiquem vinculadas ao que fora pactuado sob a ameaça de cominação de penalidade. (...) (REsp 1882117/MS, Rel. Ministra NANCY ANDRIGHI, TERCEIRA TURMA, julgado em 27/10/2020, DJe 12/11/2020).

34 (...)6. Ressalta-se que as regras relativas ao Código de Ética e Disciplina da OAB são mencionadas para fins ilustrativos da limitação da liberdade contratual na fixação de honorários advocatícios, pois
} 
SANTANA NETO, Hamilton Gomes de. Ética como valor normativo na conduta do advogado: responsabilidade democrática no acesso à justiça. Revista Eletrônica Direito e Política, Programa de Pós-Graduação Stricto Sensu em Ciência Jurídica da UNIVALI, Itajaí, v.16, n.3, 30 quadrimestre de 2021. Disponível em: www.univali.br/direitoepolitica - ISSN 1980-7791.

Perceba-se, entretanto, que o próprio EOAB trata expressamente acerca da ética do advogado, no Título I, Capítulo VIII (arts. 31 a 33).

Mais especificamente, no art. 33 do EOAB dita que o advogado deverá obedecer ao Código de Ética e Disciplina ${ }^{35}$.

Vale rememorar que tal Código, em verdade, não é tido como Lei Federal, fato que, apesar de notável, não deve interferir no valor normativo das regras de condutas morais de tal categoria profissional.

O ordenamento jurídico vai muito adiante da lei. Esta é importante, por óbvio, mas não é tudo.

Rememorando os ensinamentos de Eros Grau, norma é gênero do qual são espécies as regras e os princípios ${ }^{36}$.

Ora, se a norma a ser observada deriva não apenas de lei (regra), mas também de princípios (plano axiológico) e se a ética traz em sua essência valores a nortear a moral, por que então não conferir, às condutas morais, valor normativo a torná-la obrigatórias no seio daquela sociedade?

Repise-se, a ética é verdadeiro paradigma comportamental das condutas de uma sociedade. Logo, suas condutas moralmente aceitas, apesar de variáveis conforme tempo e espaço, bebem dos primados da ética, dos preceitos humanos mais singelos e elementares para a "boa vida"37.

não se enquadram no conceito de lei federal (art.105, III, da CF).(REsp 1903416/RS, Rel. Ministro HERMAN BENJAMIN, SEGUNDA TURMA, julgado em 02/02/2021, DJe 13/04/2021).

$35 \mathrm{EOAB}$, Art. 33. O advogado obriga-se a cumprir rigorosamente os deveres consignados no Código de Ética e Disciplina. Parágrafo único. O Código de Ética e Disciplina regula os deveres do advogado para com a comunidade, o cliente, o outro profissional e, ainda, a publicidade, a recusa do patrocínio, o dever de assistência jurídica, o dever geral de urbanidade e os respectivos procedimentos disciplinares.

${ }^{36} \mathrm{GRAU}$, Roberto Eros. O direito posto e o direito pressuposto. Malheiros Editores Ltda. São Paulo, 1996, p. 20.

37"É a ciência do comportamento moral do homem em sociedade. Mais singelamente, aproxima-se de moral, porque ambas têm idêntica raiz: os costumes consolidados após longa reiteração, porque naturais, ínsitos à natureza humana."(NALINI, José Renato, "Por que filosofia?", São Paulo: Editora Revista dos Tribunais, 2012). 
SANTANA NETO, Hamilton Gomes de. Ética como valor normativo na conduta do advogado: responsabilidade democrática no acesso à justiça. Revista Eletrônica Direito e Política, Programa de Pós-Graduação Stricto Sensu em Ciência Jurídica da UNIVALI, Itajaí, v.16, n.3, 30 quadrimestre de 2021. Disponível em: www.univali.br/direitoepolitica - ISSN 1980-7791.

Tal raciocínio, de não olvidar a carga valorativa da ética em reflexão nas condutas morais do advogado, ganha mais destaque quando tratamos de tal categoria profissional.

É que, consoante já salientado, o advogado lida com interesses humanos, razão pela qual está de frente a valores de primeira grandeza, sujeitos que jamais devem ser utilizados como meio para satisfazer demandas temerárias ou em busca do lucro a qualquer custo ${ }^{38}$.

\section{CONSIDERAÇÕES FINAIS}

Diante do exposto, pode-se concluir que o advogado não é fim em si mesmo e não deve agir com base na sua "ética da convicção"39, pois carrega consigo mister constitucional de função essencial à justiça, tendo nítido impacto na realidade social, como demonstrado através do grande número de ações judiciais em trâmite do Poder Judiciário.

Além disso, sua atuação não deve ser limitada ao "processo judicial", detendo autonomia e independência capazes de apaziguar os conflitos sociais para além das portas do Estado, pois seu "múnus" também é de importância pública.

Apesar do Código de Ética da categoria não deter natureza de lei (regra), significa sim norma a ser observada, muito porque o conceito desta engloba também os

\footnotetext{
${ }^{38}$ Pois bem, o ser humano, como natureza racional, existe como valor absoluto e fim em si e, por isso, constitui-se como a base da lei prática. O ser humano não deve, por conseguinte, absolutamente ser usado como meio, mas tão-somente como fim em si mesmo, devendo ser chamado de pessoa e não de coisa, porque, enquanto esta possui valor relativo, aquela é fim em si mesmo, possui valor absoluto e, portanto, dignidade. (NODARI, Paulo César. A teoria dos dois mundos e o conceito de liberdade em Kant. Caxias do Sul: Educs, 2009, p. 207).

39"Qualquer ação eticamente orientada pode ajustar-se a duas máximas, fundamentalmente diferentes entre si e irremediavelmente opostas: pode orientar-se de acordo com a "ética da convicção" ou de acordo com a 'ética da responsabilidade"" (WEBER, Max. Religião e racionalidade econômica. In COHN, Gabriel (org.). Weber. Col. Grandes Cientistas Sociais n. 13. São Paulo: Ática, 1979, p. 85).
} 
SANTANA NETO, Hamilton Gomes de. Ética como valor normativo na conduta do advogado: responsabilidade democrática no acesso à justiça. Revista Eletrônica Direito e Política, Programa de Pós-Graduação Stricto Sensu em Ciência Jurídica da UNIVALI, Itajaí, v.16, n.3, 30 quadrimestre de 2021. Disponível em: www.univali.br/direitoepolitica - ISSN 1980-7791.

valores e, sendo a ética tal primado, deve sim ser observada como paradigma a ser seguido.

A expressão de tal valor ético, sob viés normativo, ou seja, de obediência salutar, deve ser reiteradamente incentivada através das condutas morais no meio social, razão pela qual o fortalecimento do respeito e credibilidade social da categoria profissional em análise dependem, sobremaneira, desta.

Este raciocínio é corroborado pelo próprio Estatuto da Ordem (EOAB) que, em seu art. 31, elucida a necessidade do patrono em se portar de forma a merecer respeito, mormente por ser parte de uma classe maior ${ }^{40}$.

É dizer, o próprio advogado é quem deve, reiteradamente, através de suas condutas morais (socialmente louváveis), buscar a vigilância de seus atos, numa preocupação coletiva e não apenas individual.

Tal postura, a nível institucional da advocacia, significa numa propagação dos preceitos éticos universais de modo que o distanciamento das balizas morais daquele grupo coletivo estará fadado à destruição do meio social paulatinamente, considerando que a ética ${ }^{41}$ é, em essência, valor humano indispensável à sua existência digna.

Logo, o profissional da advocacia tem dupla responsabilidade; é dizer, presta-se aos interesses de seu cliente e, também, da sociedade em que vive, devendo seus atos se pautarem nos preceitos da teoria ética, inerente e elementar ao ser humano, através da reiteração de suas condutas.

\footnotetext{
${ }^{40} \mathrm{EOAB}$, Art. 31. O advogado deve proceder de forma que o torne merecedor de respeito e que contribua para o prestígio da classe e da advocacia.

41 "É um conjunto de valores e regras de ação propostas aos indivíduos e aos grupos por intermédio de aparelhos prescritivos diversos, como podem ser a família, as instituições educativas, as Igrejas, etc" (FOUCAULT, Michel. História da Sexualidade II, O Uso dos Prazeres. Rio de Janeiro: Ed. Graal 1984, p. 26).
} 
SANTANA NETO, Hamilton Gomes de. Ética como valor normativo na conduta do advogado: responsabilidade democrática no acesso à justiça. Revista Eletrônica Direito e Política, Programa de Pós-Graduação Stricto Sensu em Ciência Jurídica da UNIVALI, Itajaí, v.16, n.3, 30 quadrimestre de 2021. Disponível em: www.univali.br/direitoepolitica - ISSN 1980-7791.

Estas condutas, como dito, não devem destoar dos costumes sociais do local, ou seja, da moral vigente, devendo tal preocupação ser encarada como valor de norma, ou seja, de observância obrigatória.

Mesmo que esta espécie de norma ampla e principiológica não traga consigo sanção coercitiva para reprimir eventual desobediência, esta, por si só, já exprime verdadeira penalidade ao meio social em que vive o profissional da advocacia, pois supostas condutas imorais distanciam-se da diretriz ética do ser humano na busca do bem comum, caminho suficiente para pôr em cheque a "maior felicidade" do coletivo $^{42}$.

\section{REFERÊNCIAS DAS FONTES CITADAS}

ADEODATO, João Maurício. Ética e retórica: para uma teoria da dogmática jurídica. Saraiva: 2002;

BRASIL. Conselho Nacional de Justiça. Justiça em Números. 2020. Disponível em https://www.cnj.jus.br/wp-content/uploads/2020/08/.pdf. Acesso em maio/2021;

BRASIL Constituição da República Federativa do Brasil de 1988. Brasília, DF, 05.10.1988;

BRASIL Lei no 8.906, de 4 de julho de 1994.Dispõe sobre o Estatuto da Advocacia e a Ordem dos Advogados do Brasil (OAB). Diário Oficial da União, Brasília, DF, 05.07.1994;

BRASIL Superior Tribunal de Justiça. REsp 1656322/SC, Rel. Ministro ROGERIO SCHIETTI CRUZ, TERCEIRA SEÇÃO, julgado em 23/10/2019, DJe 04/11/2019;

BRASIL Superior Tribunal de Justiça. REsp 1903416/RS, Rel. Ministro HERMAN BENJAMIN, SEGUNDA TURMA, julgado em 02/02/2021, DJe 13/04/2021;

BRASIL Superior Tribunal de Justiça. REsp 1877742/DF, Rel. Ministra NANCY ANDRIGHI, TERCEIRA TURMA, julgado em 16/03/2021, DJe 25/03/2021;

BRASIL Superior Tribunal de Justiça REsp 1882117/MS, Rel. Ministra NANCY ANDRIGHI, TERCEIRA TURMA, julgado em 27/10/2020, DJe 12/11/2020

\footnotetext{
${ }^{42}$ BENTHAM, Jeremy. Os pensadores. São Paulo: Abril Cultural, 1979, p. 67.
} 
SANTANA NETO, Hamilton Gomes de. Ética como valor normativo na conduta do advogado: responsabilidade democrática no acesso à justiça. Revista Eletrônica Direito e Política, Programa de Pós-Graduação Stricto Sensu em Ciência Jurídica da UNIVALI, Itajaí, v.16, n.3, 30 quadrimestre de 2021. Disponível em: www.univali.br/direitoepolitica - ISSN 1980-7791.

BARBOSA, Júlio César Tadeu. O que é Justiça. São Paulo. Editora Brasiliense, $4^{a}$ edição, 1984;

BARROSO, Luís Roberto. A Judicialização da Vida e o Papel do Supremo Tribunal Federal. Belo Horizonte: Forum, 2018.

BENTHAM, Jeremy. Os pensadores. São Paulo: Abril Cultural, 1979;

CAPPELLETTI, Mauro. Formações sociais e interesses coletivos diante da Justiça Civil. Revista de Processo. São Paulo. Ed. RT, ano 2, v. 5, p. 122-159, jan./mar. 1977.

DALLARI, Dalmo de Abreu. Elementos de teoria geral do Estado. 31 ed. São Paulo: Saraiva, 2012;

DURKHEIM, É. Da divisão do trabalho social. São Paulo: Martins Fontes, 1999;

FOUCAULT, Michel. História da Sexualidade II, O Uso dos Prazeres. Rio de Janeiro: Ed. Graal, 1984;

GIDDENS, Anthony. As consequências da modernidade. Tradução de Raul Fiker. São Paulo: Editora UNESP, 1991

GRAU, Roberto Eros. O direito posto e o direito pressuposto. Malheiros Editores Ltda. São Paulo, 1996;

HABERMAS, Jürgen. A ética da discussão e a questão da verdade. Tradução Marcelo Brandão Cipolla. 2a ed. São Paulo: Martins Fontes, 2007;

KANT, Immanuel. Fundamentação da metafísica dos costumes. Trad. de Guido Antônio de Almeida. São Paulo: Discurso Editorial: Barcarolla, 2009;

LÔBO, PAULO LUIZ NETTO. Comentários ao Estatuto da Advocacia e da OAB. São Paulo: Saraiva, $10^{a}$ ed., 2017;

MARINONI, Luiz Guilherme; ARENHART, Sérgio Cruz. Curso de direito processual civil: Procedimentos Especiais. 4. ed. São Paulo: Revista dos Tribunais, 2013, V. 5;

NADER, Paulo. Introdução ao estudo do direito. 34a ed. Rio de Janeiro:Forense, 2012;

NALINI, José Renato. Ética geral e profissional. 7 ed. São Paulo: Editora Revista dos Tribunais, 2009;

NALINI, José Renato, "Por que filosofia?", São Paulo: Editora Revista dos Tribunais, 2012;

NODARI, Paulo César. A teoria dos dois mundos e o conceito de liberdade em Kant. Caxias do Sul: Educs, 2009; 
SANTANA NETO, Hamilton Gomes de. Ética como valor normativo na conduta do advogado: responsabilidade democrática no acesso à justiça. Revista Eletrônica Direito e Política, Programa de Pós-Graduação Stricto Sensu em Ciência Jurídica da UNIVALI, Itajaí, v.16, n.3, 30 quadrimestre de 2021. Disponível em: www.univali.br/direitoepolitica - ISSN 1980-7791.

RAMOS FILHO, Carlos Alberto de Moraes. Curso de direito financeiro. São Paulo. Saraiva, 2012;

RAMOS FILHO, Carlos Alberto de Moraes; CASAS MAIA, Maurílio. A defensoria pública como expressão e instrumento do regime democrático. In. Democracia e constitucionalismo: riscos, pressões e resiliência. Org. Rafael da Silva Menezes. 1 ed. Manaus/AM: Green Tree Books Edições Jurídicas, 2021;

SANDER, Frank E. A. The Multi-Door Courthouse: Settling Disputes in the Year 2000. Hein Online: 3 Barrister 18, 1976;

SANDER, Frank E. A. Varieties of dispute processing. In: Levin, L. A.; Russel, W. R. (Edit.). The pound conference: perspectives on justice in the future. Saint Paul: West Publishing Co., 1979;

SARLET, Ingo Wolfgang. A eficácia dos Direitos Fundamentais. 10. ed. Porto Alegre: Livraria do Advogado, 2009;

SCHELER, Max. Esencia y formas de la simpatía. Buenos Aires: Editorial Losada, S.A., 2004;

REALE, Miguel. Lições preliminares de Direito. 27 ed. São Paulo: Saraiva, 2002;

ROSSI, João Baptista Prado. Reflexões sobre a advocacia e a magistratura. São Paulo: OAB-SP, 1990;

WEBER, Max. Religião e racionalidade econômica. In COHN, Gabriel (org.). Weber. Col. Grandes Cientistas Sociais n. 13. São Paulo: Ática, 1979. 